\title{
THE UTILIZATION OF MOBILE DEVICES FOR IMPROVING ACCESS TO ONLINE LEARNING FOR DISTANCE EDUCATION'S STUDENTS
}

\author{
Dr. Dewi PADMO \\ ORCID: 0000-0002-7358-5519 \\ Faculty of Education and Teacher Training, Universitas Terbuka \\ Jakarta, Indonesia \\ Olivia IDRUS \\ ORCID: 0000-0003-4424-5491 \\ Faculty of Economics, Universitas Terbuka \\ Jakarta, Indonesia \\ Dr. Lidwina Sri ARDIASIH \\ ORCID: 0000-0001-7827-1730 \\ Master's Program in English Education \\ Faculty of Education and Teacher Training, Universitas Terbuka \\ Jakarta, Indonesia
}

Received: 18/04/2018 Accepted: 16/10/2018

\begin{abstract}
Recent advances in mobile devices have opened up opportunities for every individual to be able to communicate and obtain information quicker. Users of mobile devices in Asia now account for $49 \%$ of mobile device users in the world. This growth is partly supported by the rapid development of the Internet use. Indonesia has a potentially huge market in the use of mobile devices and Internet. The extent of utilization of mobile devices by the students pursuing higher education, especially at Universitas Terbuka (UT), is an important component of this development. This study seeks to develop an understanding of the following issues: (1) the types of the mobile devices that are used by students, (2) the types of learning and information accessed through mobile devices, (3) the time used to access learning through mobile devices, (4) the degree of students' satisfaction in using the mobile devices for learning, and (5) the effectiveness of using mobile devices for learning. The data of this research were collected by using an online questionnaire containing 26 questions. The questionnaires were distributed to UT students from four faculties and the Graduate Programs from all UT's regional offices at 38 locations spread across Indonesia, including UT's regional office for overseas student. Overall, there were 767 respondents. The results of this research show that the utilization of mobile devices, especially in the use of smartphones to access UT's online learning, seems to have great potential.
\end{abstract}

Keywords: Mobile devices, online learning, e-learning, distance education.

\section{INTRODUCTION}

The ubiquity of mobile technology has opened up unprecedented opportunities for individuals to communicate more quickly and obtain information much more easily. The forms of mobile devices that are already in wide use in Asia, including Indonesia, are very diverse and range from mobile phones with the capability to sms (short message service), take and send pictures, as well as the ability to send audio messages, up to a smartphones 
which have an operating system that serves as a pocket computer. According to Worldstats 2017, the use of the Internet in Asia reached 49.8\% of Internet users across the world (http://www.internetworldstats.com/stats.htm). This suggests that the use of the Internet in Asia is very high. Also the number of people owning mobile devices is increasing rapidly.

Utilization of internet and mobile devices in Indonesia also shows a rapid increase. As a country with a population of approximately 263.5 million, Internet users in Indonesia have already reached 132.7 million in 2017 (http://www.internetworldstats. com/stats.htm). This puts Indonesia in the third place in the world in terms of the number of Internet users. Moreover, the growth in mobile communication has been exceptionalpresently, there are 270 million of mobile phone users in Indonesia (Gusti, 2014). This number is larger than the number of people in Indonesia. This means that one person has more than one mobile device on average. The highest ratio of the mobile phone ownership is mainly found in Jakarta; it has 1.8 mobile phones per person (Gusti, 2014). Data collected in 2012 by the Indonesian Association of Internet Service Providers (APJII) shows that 65\% of Internet users in Indonesia use mobile devices (Susanto, 2013). In 2017 the number of mobile phone users who accessed the internet from their mobile phone reached $28.78 \%$ of Indonesian population. Furthermore, it is estimated that $40.57 \%$ of the Indonesian population would have access to the Internet via their mobile phones by 2022 (https://www.statista.com/statistics/309017/indonesia-mobilephone-internet-user-penetration, 2018). This indicates that mobile device has become the most convenient medium to connect with the outside world. A survey conducted, showed that nearly all mobile internet users (87.3\%) use Android smartphone (Alia \& Ngasis, 2014).

Baggaley (2007), while observing the development of mobile device users in Asia, speculated the possibility of Asia leading the world in terms of the absolute number of mobile users. This expectation is also supported by Ambient Insight Regional Report (Adkins, 2015) which states that Asia is the most dynamic and unique market of mobile learning. Revenue from mobile learning is estimated to reach US \$ 7.7 billion as early as in 2019 .

According to recent surveys examining the implementation of mobile learning at the level of institutions or providers of learning programs, data shows that $37 \%$ of respondents stated they had implemented mobile learning (Padmo, Huda, Sriasih, \& Idrus, 2013). Other data related to the utilization of mobile learning research conducted by Padmo, et al. (2013) showed a majority of respondents (61\%) had disseminated information to students through mobile technology. Similarly, regarding the use of mobile learning management system (LMS), 37\% of respondents stated that they had already implemented LMS in their institution. These data indicate that a number of respondents representing institutions or organizations engaged in education and training have already been taking extensive advantage of mobile learning.

With regard to online learning, Universitas Terbuka (UT), a university applying open distance learning system, has been utilizing online teaching/learning assistance since 2002. However, to what extent UT's students take advantage of mobile devices for learning or accessing learning materials provided by UT and other material of Open Educational Resources (OER) remains unknown. This has led researchers to focus on the use of mobile devices in accessing learning or other material related to the learning both provided by UT and open educational resources of various material providers.

\section{DEFINITION OF MOBILE DEVICES AND MOBILE LEARNING}

Most definitions of mobile learning emphasize the use of wireless technologies to differentiate it from other forms of learning. Shon (2008) defines mobile learning as the use of computer technology that is mobile and 
cordless. Naismith, Lonsdale, Vavoula, and Sharples (2004) emphasize the importance of portable technology devices that makes it easier to learn in various locations. Such devices include a handheld or portable device such as laptop, iPad/Tablet or smartphone. Keegan (2005) also defines mobile learning as education and training through a PDA (Personal Digital Assistants)/palmtops/handhelds, smartphones and cellular (mobile phones). Likewise, ISO/IEC (2011) defines mobile learning as a learning process that uses information and communication technology (ICT) in a mobile context.

O'Malley, Vavoula, Glew, Taylor, Sharples, and Lefrere (2004) state that mobile learning refers to the various forms of learning that happen when the learner is at a location that is not fixed and cannot be pre-determined, so learners could get benefit from the learning opportunities offered by mobile technologies. This definition of mobile learning also includes other elements and perspectives. According to Sharples, Taylor, and Vavoula (2007), mobile learning is a process of acquiring knowledge through conversation in a variety of contexts between humans and interactive technologies in a personal way. Laurillard (2007) believes that mobile learning assists in a digital form by making learning easy in adjustment, based on research, communicative, collaborative, and productive in a remote location that offers a wide variety of contexts that can be operated by the teacher.

\section{Functions and Benefits of Mobile Learning}

According to Panjaitan (2012), mobile learning supporting learning activities in the classroom serves as a supplement that can be seen as optional, complementary or a replacement. Mobile learning as a supplement means that learners have the freedom to decide whether to take advantage of mobile learning materials or not. Mobile learning that serves as a complementary means that the material is programmed to complete the learning materials received by the students in the classroom or as a reinforcement or remedial material. The third is to see it as a replacement or substitution. Some universities in developed countries have come up with alternative models of learning activities. Whatever the form, the goal is that learners can flexibly manage lecture activities in accordance with the time and daily activities of learners.

Utilization of mobile learning can be seen from two viewpoints, i.e. from the perspective of learner and that from tutor/educator (Miftah, 2012). For learners, mobile learning enables high learning flexibility. Learners get access to learning materials as well as the opportunity to communicate with the tutor/educator at any time. In terms of availability of infrastructure facilities that have reached remote areas, mobile learning is beneficial for students in the following ways: (1) getting learning materials that are not provided by the school, (2) participating in home schooling education, (3) continuing education for those who have dropped out of school, and (4) providing an opportunity for those who do not attend conventional face-to-face school. According to Burton etal. (2015), the advantages of using mobile learning include the fact that it makes the learning process more flexible and accessible. With mobile devices, learners can easily access learning resources within their working schedule and still be able to pursue other commitments in their lives. This leads to increased access to higher education.

As for the utilization of mobile learning, according to Miftah (2012), there are at least four benefits. Firstly, it enhances interactivity between learners and tutors/educators, between learners and other learners, and between learners and learning materials. Hence, mobile learning enables all learners to interact. The second benefit is the time and place flexibility it provides by enabling learning interactions anywhere and at any time. Third, mobile learning enables reaching a global audience. With the flexibility of time and place, learners can be reached from wider areas and more easily. The final benefit is the ease of updating content and archival capabilities. There is little doubt that the utilization of various software and the Internet is really useful in updating learning materials frequently.

With the advancement of mobile technology that can be utilized to support learning in an Open and Distance Education set up requires researchers to conduct research on the utilization of mobile learning. This study aims 
to examine specifically the use of mobile devices by Universitas Terbuka's (UT's) students to access the learning materials provided by UT along with other learning materials in an openly accessible manner from a variety of educational portals. Specifically, this study seeks to explore (1) the types of mobile devices that are used by students, (2) the types of learning and information accessed through mobile devices, (3) the time used to access learning through mobile devices, (4) student's satisfaction in the use of mobile devices for learning, and (5) the effectiveness of using mobile devices for learning.

\section{METHODOLOGY}

\section{Participants}

There were 767 respondents participating in this study. They all came from the faculties of Economics (16.1\%), Social Science and Governance (42.2\%), Education (13.4\%), Mathematics and Natural Sciences (22.9\%), and post graduate programs (5.3\%). There were no respondents, however, from the Department of Primary School Teacher Education and Early Childhood Teacher Education since most UT students from these departments generally come from remote areas of Indonesia which have limited access to Internet connection. However, some respondents volunteered to be interviewed. There were 8 such respondents ( 3 from Bogor, 2 from Serang and 3 from Bandung).

\section{Data Collection}

Our study used two ways of collecting data, namely through online questionnaires and interviews to a number of respondents. The questionnaire contained 26 questions in the form of open and closed questions using Survey Monkey and carried out for 2 months. In addition, data were collected through interviews with some respondents with a semi- structured interview guide. The collection of data through this interview conducted at three different UT service areas enabled the capture of the necessary information from different regions.

\section{Population and Sample}

The population in this study consisted of UT students utilizing the online learning services provided by UT. In order to be representative of the prevailing conditions of the use of mobile device, respondents were chosen from various faculties with a stratified sampling. The sample size was based on the proportion of the total population. There were three variables or stratification criteria, namely: (1) faculty, (2) the study program, and (3) regions. In this way, the research could focus on the subpopulations representative of UT students in Indonesia. In order to achieve a good response rate despite the existence of various subpopulations, a systematic sampling method was used. Furthermore, out of the respondents who answered the questionnaire, a number of respondents volunteered to be interviewed in the focus group discussion.

\section{FINDINGS AND DISCUSSION}

As for UT's regional office area coverage, the respondents were spread almost throughout Indonesia, by covering 38 of the 39 of UT's regional offices, including the regional office for overseas students. Most of the respondents came from Jakarta (20\%), then Bogor (9\%), and Bandung (5.6\%). This feature had already been expected since students who live in Jakarta, Bogor, and Bandung or in Java had good access to the Internet, had mobile devices, and were using them for the purpose of online learning. However, our data showed that no respondents had come from Ambon, which is located in Eastern Indonesia. The reasons need to be investigated further; whether they are caused by Internet network problems, or because of other problems. Another noteworthy feature of our data pertains to the age range of respondents (see Table 1). 
Table 1.Distribution of respondents' age range

\begin{tabular}{cc}
\hline Ages range & Response Percent \\
\hline$<20$ & 7.6 \\
$20-25$ & 32.6 \\
$26-30$ & 27.3 \\
$31-35$ & 15.0 \\
$36-40$ & 8.8 \\
$40-45$ & 5.0 \\
$>45$ & 3.7 \\
\hline
\end{tabular}

The table shows that the greatest age range of respondents were students aged between 20 and 25 years (32.6\%) and between 26 and 30 years $(27.3 \%)$. This shows that the most active mobile device users were relatively young. As for gender, the numbers of female respondents (48.1\%) and men (51.9\%) were almost equal. As for employment status, the data showed that most of the respondents consisted of students working in the private sector (49.4\%) and civil service (19.4\%). Other respondents recording large percentages included students working in other sectors such as private business, foreign labour, and contract worker (17\%), unemployed $(10.6 \%)$, and the police/military $(2 \%)$ and state-owned enterprise (1.6\%). The educational badkgrounds of the respondents were quite varied: most were high school graduates $(71.7 \%)$, then vocational school graduates $(17.8 \%)$, Bachelor (12.2\%), and Postgraduate (0.9\%).

\section{Usage of Various Types of Mobile Devices}

There were many types of mobile telecommunication devices being used by UT students both for communication purposes and to access online learning. These included hand phones, smartphones, tablets, netbooks, notebooks/laptops, portable media players, and PCs. Figure 1 shows that the smartphones (59.5\%) and notebooks/laptops (73.4\%) were the most widely used.

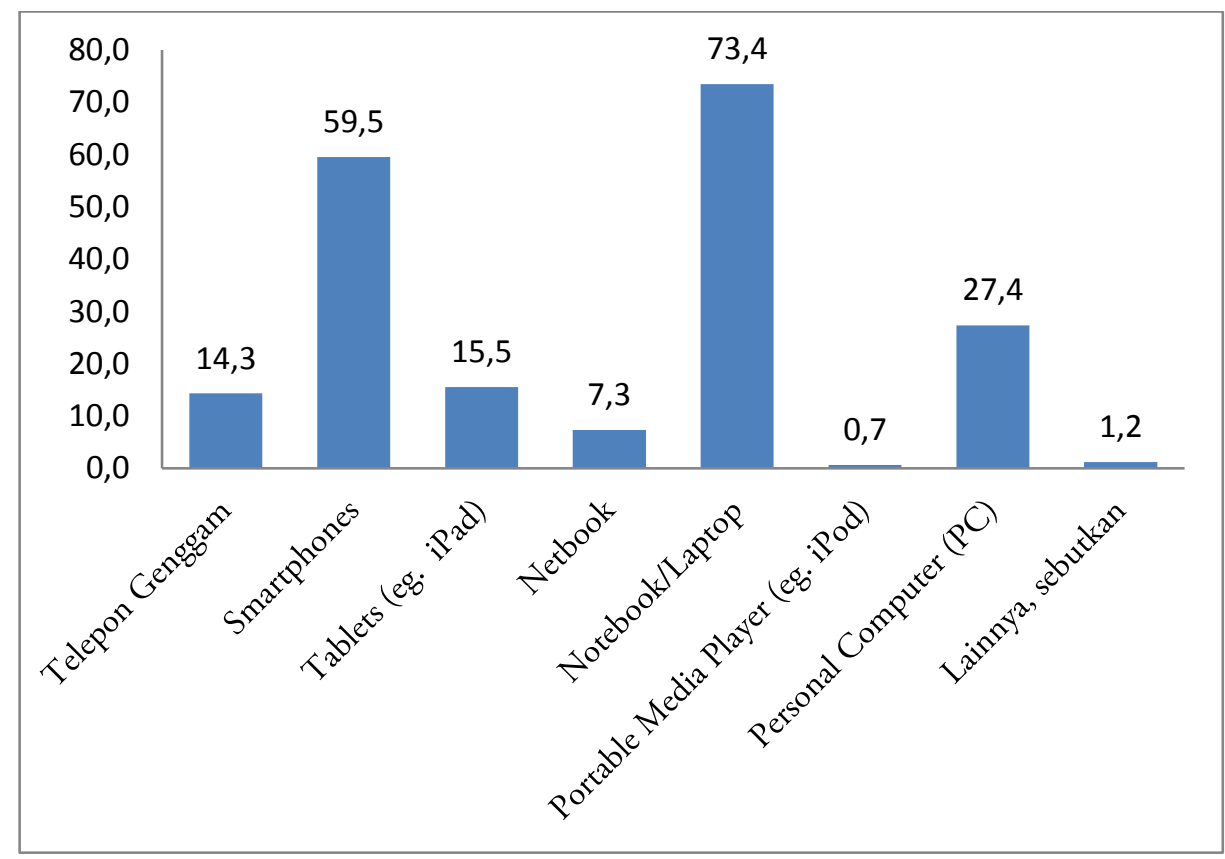

Figure 1. Usage of various types of mobile device

The operating systems for the smartphones being used by respondents was also quite varied. Among the main brands in use were Blackberry, iPhone, Android, Windows Mobile, and Web OS. Figure 2 shows that most of the respondents (85.6\%) were using Android. 


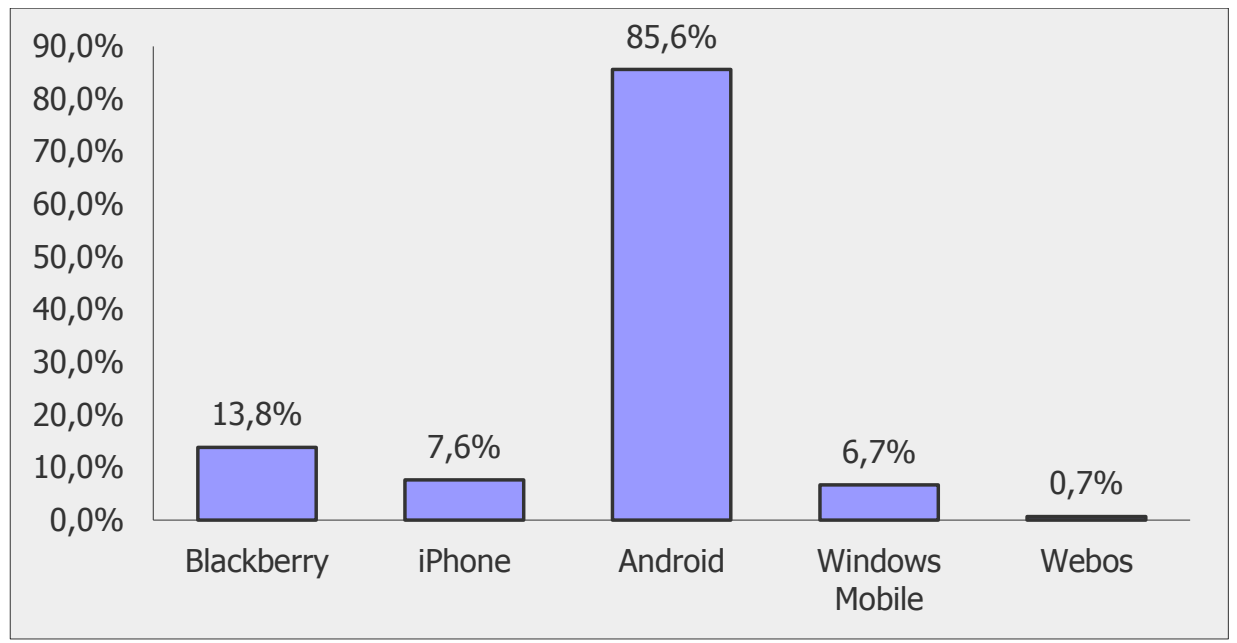

Figure 2. Usage of a smartphone operating systems

\section{Access to Types of Learning Materials and Information}

As a distance learning institution, UT provides various types of online learning materials and information that are accessible via a variety of mobile devices. The types of learning materials include online tutorials, Virtual Reading Rooms (RBV), Internet TV-UT, Teacher Online Portals (GPO), Learning Object Material (LOM), UT journals, and Dry-Lab UT. How often respondents utilize each type of online learning turned out to be an important factor to explore. Figure 3 shows data concerning the use of various types of online learning material and information by UT students. Online tutorials seemed to be the most utilized by the respondents (94\%). Other types of online learning material/information accessed by the respondents were the Social Media and News or Information of UT. However, only a few respondents were interested in accessing the other materials/information such as links to other learning resources, Internet TV UT, Virtual Reading Room (RBV), Enrichment Material, and Digital Library.

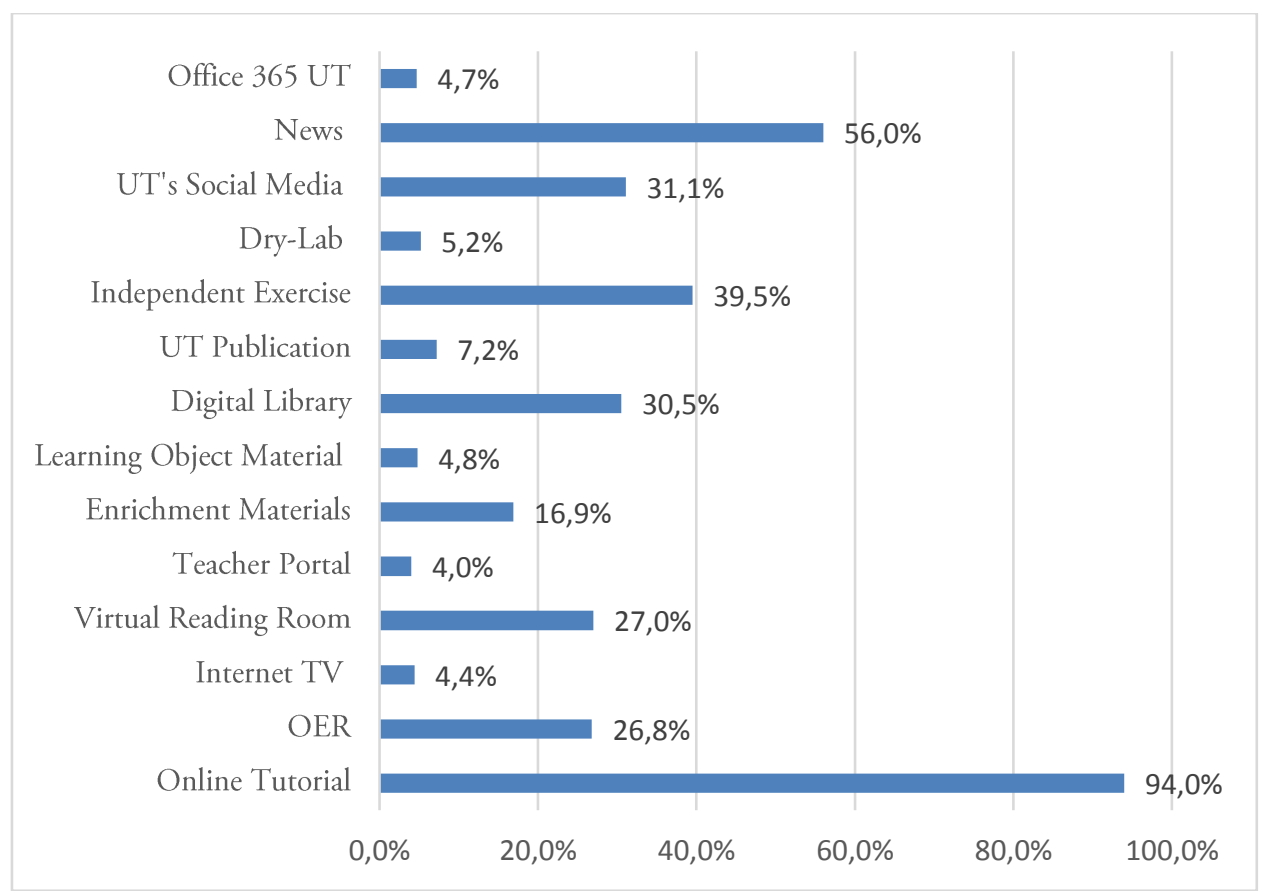

Figure 3. Types of learning material and information utilized by UT's students 
The types of learning materials most accessed by students via mobile devices were Online Tutorials (94\%), then news or announcements as much as $56 \%$. Other types of learning accessed by students ranged between $25 \%$ and $40 \%$.

\section{Utilization of UT's Online Services}

Data focusing on UT's information services which included email, social media, learning support, news/information, and video Open Educational Resources (OER). It can be seen from Figure 4 that email was most frequently used by UT students ( $41 \%$ of respondents), followed by the use of social media as much as $35 \%$ of respondents. Other services used quite often included assistance in learning via online tutorials, virtual reading room, etc. ( $43 \%$ of respondents) and news/general information ( $45 \%$ of respondents). Surprisingly video content from multiple sources as UT's service was rarely used by the majority of respondents (43\%).

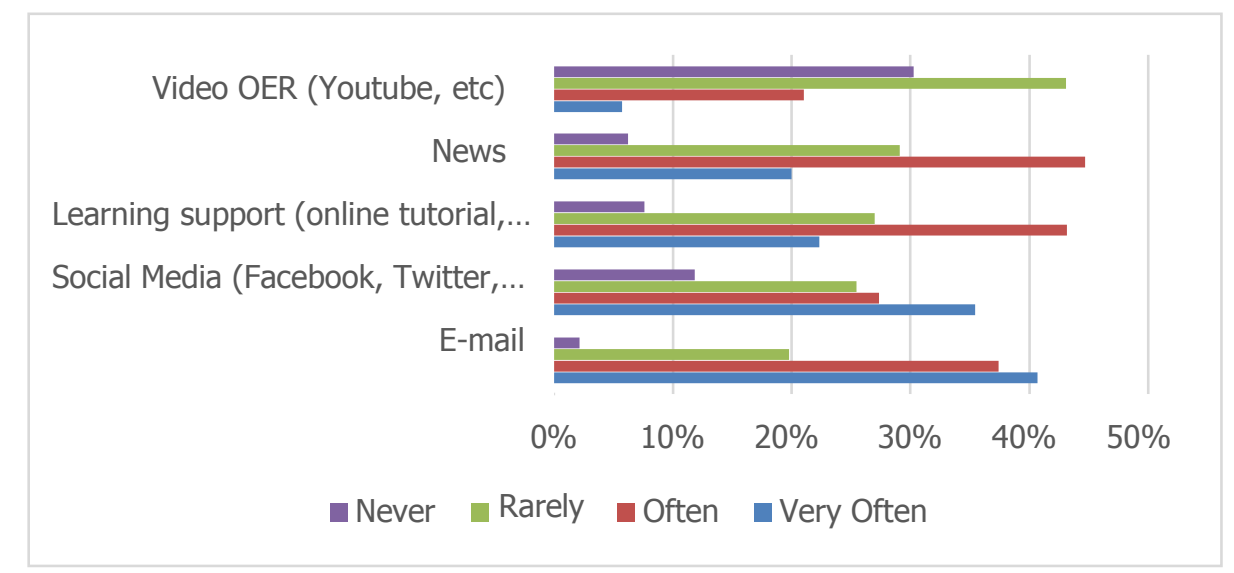

Figure 4. Utilization of UT's online services

One aspect that needed to be explored further related to the frequency of mobile device usage for learning purposes. Our data showed that $30 \%$ of respondents were using mobile devices to access the online learning every day, of which 70\% were accessing 1-2 times a day, 21\% accessing 3-4 times a day, and 9\% more than 4 times a day. Another aspect that was interesting concerned the duration of time used by respondents when they access online learning using their mobile device. We found that $33 \%$ of respondents were using their mobile devices for 15-30 minutes each time, $20 \%$ for 36-60 minutes, and $25 \%$ one hour or more. As for the most convenient time for accessing online learning via a mobile device, $72 \%$ were using them during night-time and $33 \%$ respondents during day-times (see Figure 5). This is understandable since a majority of distance education students usually work during the day.

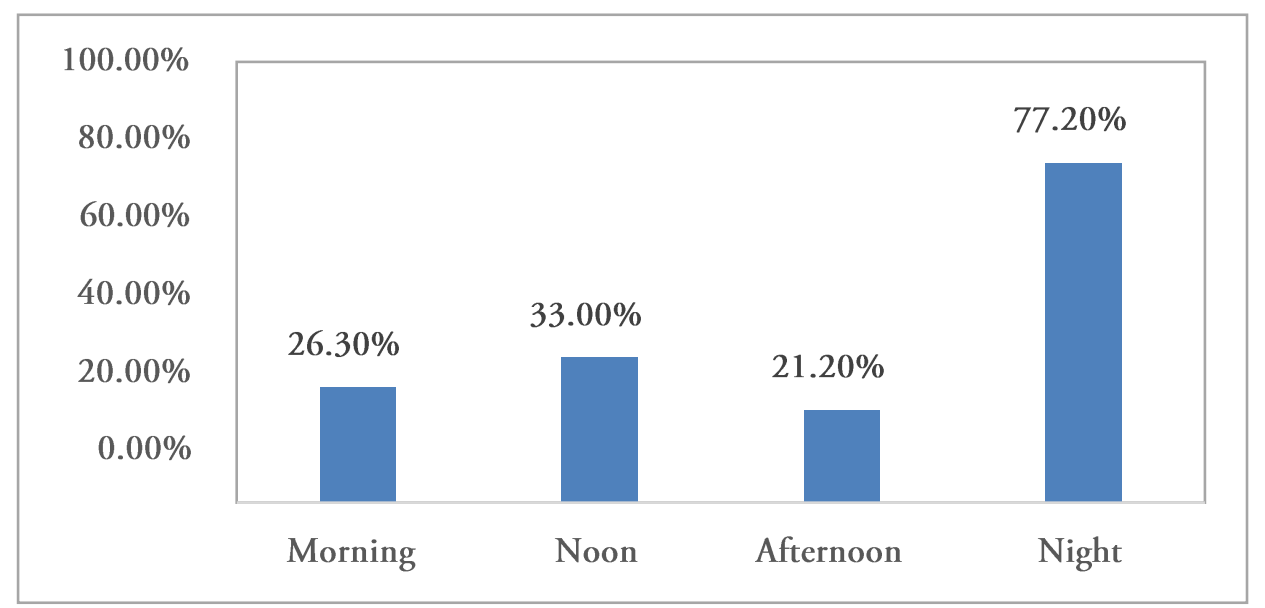

Figure 5. Time utilization of mobile devices by UT's students for accessing online learning 
Mobile devices enable everyone to access online learning from anywhere. Our results indicate that the majority (54\%) of respondents were using their mobile devices for accessing online learning at home and $30 \%$ did so at their offices (see Figure 6). This shows that, although a mobile device can be used anywhere, it seems that the house remains the most convenient place for the respondents to access online learning.

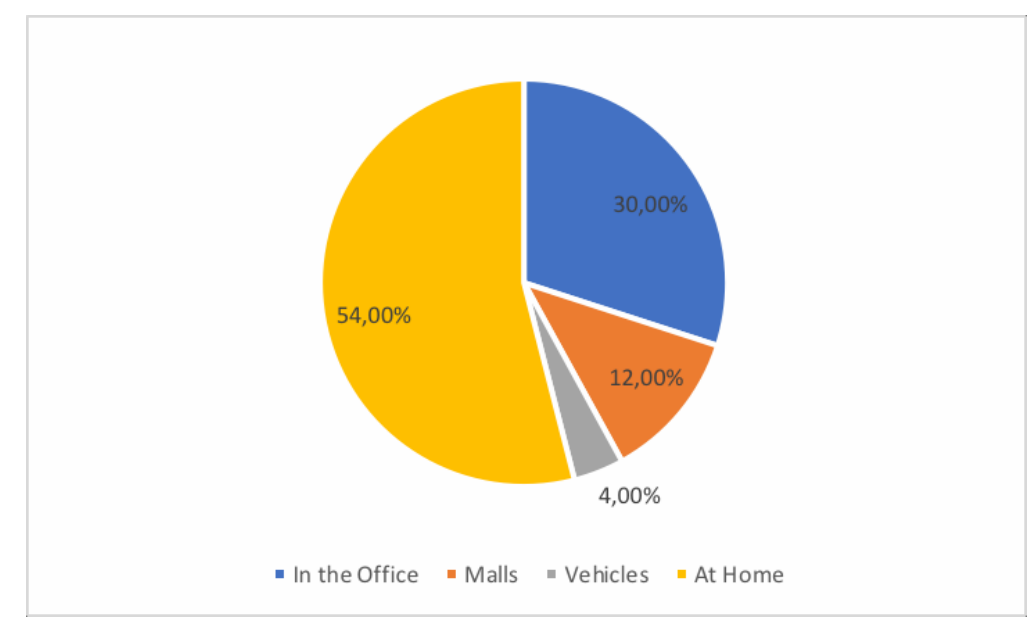

Figure 6. Locations where UT's students used their mobile devices to access the online learning

\section{Students' Satisfaction in Using Mobile Devices for Learning}

Students' satisfaction in using mobile devices for learning is an interesting factor to note because it directly influences students' success through UT's online learning utilization services. Figure 7 provides information on the levels of satisfaction in our study.

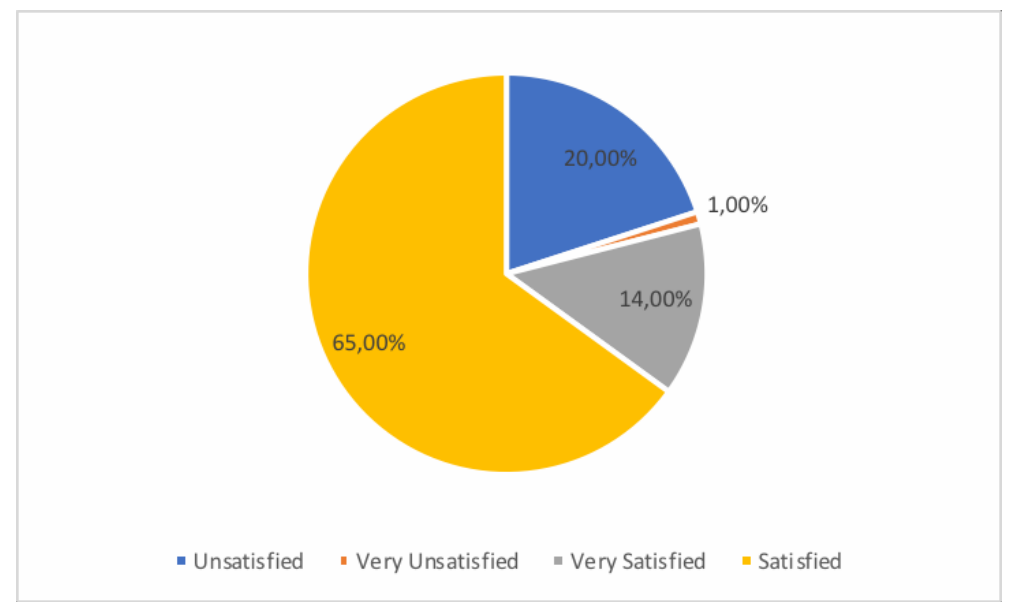

Figure 7. Students' satisfaction in using mobile devices for accessing UT's online learning

The data show that $65 \%$ of respondents were satisfied with the use of mobile devices to access UT online learning, while $20 \%$ were not. More detailed information concerning the reasons why certain respondents were not satisfied is an important issue that needs further discussion. The question is interesting since answering it throws light on the associated constraints or issues and provides valuable inputs for improving existing online learning services. Another interesting issue we examined in more detail concerned the student satisfaction levels associated with each type of online learning and information that can be accessed by respondents using their mobile devices. Table 2 shows data on the satisfaction level of students engaged in different types of online learning and information accessed using a mobile device with different number of respondents who respond to each type of the online learning provided by the University. 
Table 2. Students' satisfaction level accessing different types of online learning and information through mobile devices

\begin{tabular}{lccccc}
\hline Type of Online Learning / Information & $\begin{array}{c}\text { Very } \\
\text { Satisfied }\end{array}$ & Satisfied & $\begin{array}{c}\text { Dis- } \\
\text { satisfied }\end{array}$ & $\begin{array}{c}\text { Very Dis- } \\
\text { satisfied }\end{array}$ & $\begin{array}{c}\text { Response } \\
\text { Count }\end{array}$ \\
\hline Online tutorials & $26 \%$ & $47 \%$ & $9 \%$ & $0 \%$ & $96 \%$ \\
Link to OER & $9 \%$ & $51 \%$ & $33 \%$ & $7 \%$ & $17 \%$ \\
Internet TV UT (ITV-UT) & $0 \%$ & $14 \%$ & $43 \%$ & $43 \%$ & $5 \%$ \\
Virtual Reading Room & $22 \%$ & $33 \%$ & $30 \%$ & $15 \%$ & $12 \%$ \\
Teacher Online Portal (GPO) & $6 \%$ & $19 \%$ & $38 \%$ & $38 \%$ & $2 \%$ \\
Online Supplement & $8 \%$ & $48 \%$ & $36 \%$ & $8 \%$ & $4 \%$ \\
Learning Object Material (LOM) & $22 \%$ & $33 \%$ & $33 \%$ & $11 \%$ & $1 \%$ \\
Digital Library & $12 \%$ & $46 \%$ & $30 \%$ & $12 \%$ & $7 \%$ \\
UT Journals & $18 \%$ & $9 \%$ & $64 \%$ & $9 \%$ & $2 \%$ \\
Independent Exercises (LM) & $23 \%$ & $46 \%$ & $22 \%$ & $9 \%$ & $14 \%$ \\
UT's Dry-Lab & $0 \%$ & $33 \%$ & $33 \%$ & $33 \%$ & $1 \%$ \\
UT's Social Media (Facebook, Twitter, & $30 \%$ & $38 \%$ & $21 \%$ & $11 \%$ & $8 \%$ \\
etc.) & & & & & \\
UT News / Information & $7 \%$ & $51 \%$ & $12 \%$ & $0 \%$ & $15 \%$ \\
Office 365 UT (ecampus.ut.ac.id) & $8 \%$ & $36 \%$ & $2 \%$ & $30 \%$ & $7 \%$ \\
\hline
\end{tabular}

According to Table 2, the number of respondents who responded to the question on the satisfaction level associated with each type of online learning was varied. Online tutorials seem to be the most favored by the participants (96\%). This figure could be divided into $26 \%$ for perceiving it as very satisfied and $47 \%$ as satisfied. The other types of online learning materials and information are still relatively unsatisfactory.

The use of mobile devices to access online learning could be linked empirically to the level of motivation of the respondents. $68 \%$ of respondents were motivated to use mobile devices to access UT online learning services provided by UT while only $25 \%$ were very motivated do so. Still, these results point to an excellent opportunity for UT to continue developing its online learning materials and information that can be accessed by students via a mobile device. However, there were $6 \%$ respondents who said that they were not motivated and $1 \%$ very unmotivated. Figure 8 graphically illustrates the levels of respondents' motivation.

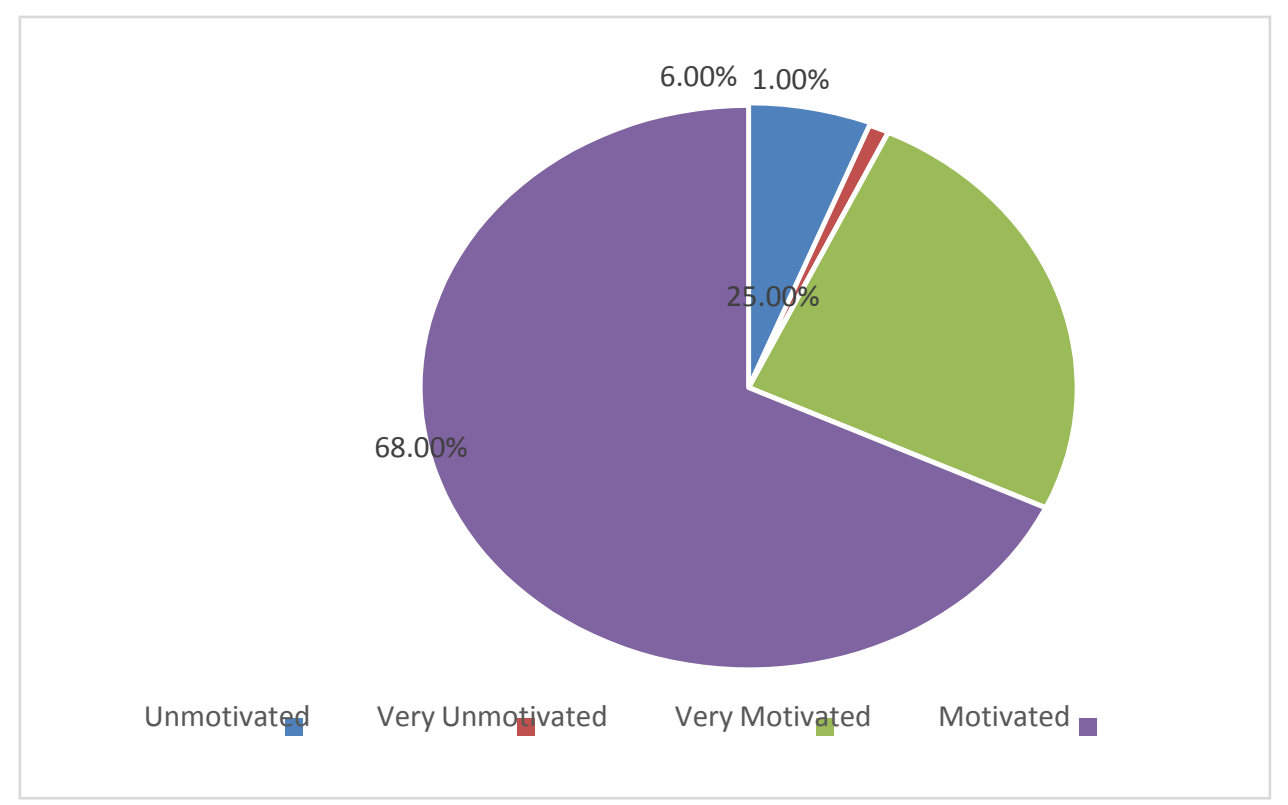

Figure 8. UT students' motivation levels in using mobile devices to access the online learning 


\section{The Effectiveness of the Use of Mobile Devices for Learning Purposes}

The effectiveness of the use of mobile devices for online learning purposes can be seen from the positive impacts felt by respondents and also seen from the constraints they faced. Table 3 lists our findings concerning the positive impacts of the use of mobile devices for online learning.

Table 3. Positive impacts of the use of mobile devices for online learning

\begin{tabular}{lc}
\hline Positive Impacts of the Use of Mobile Devices & Response Percent \\
\hline Ability to access the online learning materials anywhere, anytime & $91.0 \%$ \\
Ability to access various types of materials/information & $58.5 \%$ \\
Personal & $35.2 \%$ \\
Able to interact with the tutor as well as other participants & $39.7 \%$ \\
Comfortable & $39.2 \%$ \\
Knowledge and information exchange & $36.8 \%$ \\
Delivering notifications and reminder instantly & $37.3 \%$ \\
\hline
\end{tabular}

The biggest impact felt by respondents in using mobile devices concerned the ease of access online learning materials (91\%). By using mobile devices, respondents could access online learning anywhere and anytime and this looks very effective. Similarly, they could easily access various types of materials and information online (58.5\%). Other things that also seem to have a positive impact included personal, interacting with tutors and other students, comfortable, easy to exchange knowledge and information, and facilitate the delivery of notifications and reminders. It can be seen from Table 3 that positive impacts were felt by more than $30 \%$ of respondents.

The level of effectiveness can also be measured from the constraints faced by respondents in using mobile devices for the purposes of online learning. Table 4 shows the constraints faced by respondents in detail.

Table 4. Constraints faced by mobile device use for online learning

\begin{tabular}{lc}
\hline Constraints & Response Level \\
\hline Small screen size & $48.8 \%$ \\
Small keyboard & $24.6 \%$ \\
Limitations of Interface Usage & $31.8 \%$ \\
Learning from the separated fragments of materials & $37.7 \%$ \\
Limited memory devices & $28.3 \%$ \\
Limited connectivity/accessibility & $54.0 \%$ \\
Short battery duration & $29.7 \%$ \\
Need a monthly fee & $30.3 \%$ \\
Lack of expertise & $6.5 \%$ \\
Others, please specify! & \\
\hline
\end{tabular}

The constraints in using mobile devices for accessing online learning could be categorized into four, namely mobile devices, connectivity, contents, and cost. In terms of mobile devices, the most significant constraints perceived by respondents were small screen size $(48.8 \%)$, interface usage limitations $(31.8 \%)$, short battery duration (29.7\%), limited device memory (28.2\%), and small keyboards (24.6\%). More specifically, the connectivity aspect turned out to be the biggest constraint (54\%). Another feature acting as an obstacle to utilizing online learning through mobile devices was learning material is in fragments and separated (37.7\%). The cost factor was also a constraint felt by most of the respondents (30.3\%). 


\section{DISCUSSION}

Based on the results from our survey of mobile learning at different UT facilities, there are some interesting things to discuss regarding the definition of mobile devices, the level of satisfaction, and the effectiveness of mobile device usage. The definition of mobile devices is evolving along with the development of technology. Naismith et al. (2004) define a mobile device as a handheld or portable device such as a laptop, an iPad, or a smartphone. More generally, it is a mobile device that has been used mainly using a wireless mobile device, such as a mobile phone or a laptop computer (Schroeder, 2013). Viewed from the type of mobile devices that are widely used for the learning purposes, the results of research in Indonesia show that the most widely used mobile devices are smartphones (59.5\%) and laptops (57.8\%). This is broadly similar to the situation in China, where the mobile devices that are mostly used are tablets $(28.72 \%)$, smartphones $(24.07 \%)$ and laptops (22.91\%) (Shilang \& Hongtao, 2013). Lenhart in 2012 found that $88 \%$ of teens were using the Internet on a desktop or laptop computer while $49 \%$ were using cell phones (Schroeder, 2013). Furthermore, a meta-analysis research on the use of mobile devices in learning conducted by Baran (2014) found that mobile phones were the most widely used devices (42.5\%) while tablets (17.55\%), PDAs / Handled PCs (17.5\%), iPods (10\%), and laptops $(12.5 \%)$ were other notable devices in use. From the results of this study but also receiving significant support from other studies, it could be seen that the types of mobile devices widely used both in developed and developing countries are smartphones. The types of mobile devices used for learning are closely related to the development of technological advancements that are constantly evolving over time.

However, in terms of smartphone operating systems, most students at UT (85.6\%) were using the Android operating system. In line with another survey in Indonesia conducted by Alia and Ngasis (2014), this study yielded a similar result; $87.3 \%$ of mobile internet users were using Android phones. By contrast, based on the research results conducted by Smith et al., the use of smartphones with Android operating system in the USA was also quite large (20\%) compared with iPhones which reached just 19\% (Schroeder, 2013). The popularity of the Android operating system on the smartphone is possibly because Android has many advantages and is easy to use. However, this issue has become more and more debatable over time.

\section{Levels of Satisfaction and Motivation}

Our data show that $65 \%$ of respondents were satisfied with the use of mobile devices to access UT's online learning. Research conducted by Strong, Ho, Odom, Irby (2013) also showed that most learners believed that mobile learning contributes positively to their learning process and performance. Furthermore, Strong etal. (2013) found that learners believe that mobile learning is easy to use and the skills of mobile learning and learning through mobile will develop by itself. High motivation for mobile learning was also evident in several other studies (Uzunboylu \& Ozdamli's, 2011); they found that a positive attitude affects readiness and willingness to use mobile learning. Of course, high motivation to utilize mobile learning will greatly affect the development of mobile learning utilization, for sure.

\section{The Effectiveness of Mobile Device Usage}

The biggest impact perceived by our respondents was the ease of accessing online learning materials (91\%). By using mobile devices, respondents could access online learning anywhere and anytime. They found this to be very effective. Bidin and Ziden (2013) too came to the conclusion that the usage of mobile devices is effective because mobile devices enable "learning anywhere at anytime". Similarly, respondents can access various types 
of online materials and information much more easily (58.5\%) than otherwise. This conclusion is in line with the opinion of Miftah (2012) that the use of mobile learning enables learning interaction from anywhere and at anytime (time and place flexibility). The same thing is stated by Burton et al (2015): learning becomes more flexible and accessible through mobile learning, because learners can access learning resources anytime, anywhere. Burton et al. (2015) add that using mobile handsets for learning allows learners to learn within their work environment as well as other occupations, thereby increasing access to higher education. Similar research results are related to the flexibility of mobile learning use in medical schools in Pakistan, where learners are encouraged to use e-books and dictionaries via their mobile devices whenever needed (Imtinan, 2017). Murphy and Farley (2017) mentioned that Southeast Asia and South Korea were likewise identified as the region that supports the use of mobile technology at a very high level for learning. Meanwhile, educators in South Korea $(85 \%)$ and in Greater China (80\%) believe that mobile learning has a positive effect on education. However, a study on mobile learning in Australia and New Zealand reported that educators were less convinced (69\%) about the positive impact of mobile learning. Such different values accorded to the use of mobile learning might be related to the social influence as well as the impact of cultural perceptions and beliefs in utilizing mobile learning.

Our data show that the constraints in using mobile devices for accessing online learning could be differentiated in terms of four aspects: mobile device, connectivity, content, and cost. In terms of mobile devices, the most significant constraints perceived by respondents were small screen size $(48.8 \%)$, interface usage limitations (31.8\%), short battery duration (29.7\%), limited device memory (28.2\%), and small keyboard (24.6\%). Meanwhile, connectivity aspect turned out to be the biggest constraint (54\%). As for the obstacles to utilizing mobile learning in China, Shilang and Hongtao (2013) found that the top barriers to implementing mobile learning were limited connectivity (100\%) and limited bandwidth (79\%), small devices (about 30\%), and short battery life (60\%). The same issues were also detected by Imtinan (2017) which identified the main constraints to mobile device utilization for mobile learning to be small screens, tiny keypads, short memories and small battery capability. Issues concerning the utilization of mobile learning is generally associated with the limitations of mobile devices. It seems that this concern in the utilization of mobile learning will remain in the near future.

\section{CONCLUSION}

The utilization of mobile devices, especially in the use of smartphones to access UT's online learning, seems to have great potential. Owing to remarkable advancements of ICT technology, UT should take advantage of this opportunity because it is largely a distance education institution. Such an initiative can be expected to maximize the accessibility of UT online services through mobile smartphone devices whose applications can be downloaded through the App Store. For instance, this will enable quick access to online services via smartphones. Further the displays could be tailored to suit the smartphones that are in most use.

Clearly, institutional research related to mobile device utilization, enhancement of UT's online service quality and communication technology change are clearly needed to ensure that UT will always be able to follow the remarkable ICT development observed so far. Further research is needed in relation to student satisfaction with the accessibility of UT online services through mobile devices, and the effectiveness of mobile learning through other mobile devices, especially smartphones. 


\section{BIODATA and CONTACT ADDRESSES of AUTHORS}

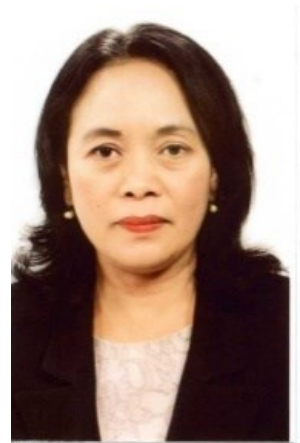

Dewi PADMO is an Associate Professor of the Faculty of Education and Teachers Training at Universitas Terbuka Indonesia. She holds her Doctor of Philosophy in Instructional System at Florida State University - USA in April, 2012. Upon returning to Indonesia, she was assigned as the Head of Institute for Research and Community Services of UT. Following from her work at the Research Institute, she served as a Vice Rector for Finance and General Affair of the Universitas Terbuka from 2014-2018. Her research interests mostly on team work, mobile learning, interactive learning material, learning analytics, and use of technology in open and distance learning. In the last couple of years, she has been involved in number of research projects on mobile learning and collaborative online learning. She has published some journal articles and some international book chapters.

Dewi PADMO

Department of Educational Technology, Faculty of Education and Teachers Training

Address: Universitas Terbuka, 15418, Tangerang Selatan, Indonesia

Phone: +62 217490941 ext. $2028 /+6285614666593$

E-mail: dewi@ecampus.ut.ac.id

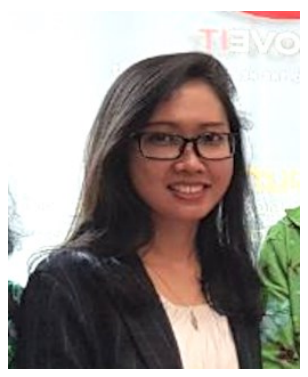

Olivia IDRUS is a lecturer in economics faculty of Universitas Terbuka. She holds a bachelor degree in Accounting from University of Trisaksi, Jakarta - Indonesia. In 2008 she received a scholarship from the Ministry of Communication and Information of the Republic of Indonesia to pursue her Master degree in Management in University of Groningen, Netherlands. Her research interests include accounting, management and ODL (Open and Distance Learning).

\section{Olivia IDRUS}

Accounting Department, Faculty of Economics

Address: Universitas Terbuka, Jalan Cabe Raya, Pondok Cabe, Tangerang Selatan,

Banten 15418 Indonesia

Phone: +62 217490941 ext 1102

E-mail: olivia@ecampus.ut.ac.id

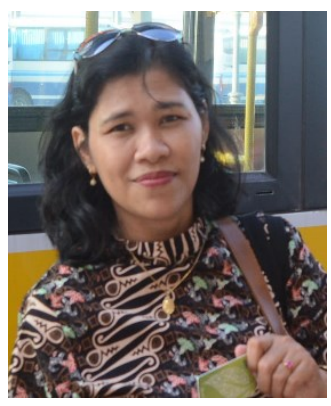

Lidwina Sri ARDIASIH is an Associate Professor of the Faculty of Education and Teacher Training at Universitas Terbuka Indonesia. She pursued her Master of Education at the University of Western Australia in 2011. Her doctoral degree in Language Education was gained at Universitas Negeri Jakarta in February, 2019. Her academic interest areas are open and distance learning, e-learning, and English language teaching. She has published some journal articles and conference papers in English language teaching for distance learners in higher education.

\section{Lidwina Sri ARDIASIH}

Master's Program in English Education, Faculty of Education and Teacher Training

Address: Universitas Terbuka, Jalan Cabe Raya, Pondok Cabe, Tangerang Selatan,

Banten 15418 Indonesia

Phone: +62 217490941 ext. 2028 / +62 81310033593

E-mail: lidwina@ecampus.ut.ac.id / wina.pbis@gmail.com 


\section{REFERENCES}

Adkins, S.S. (2015). Ambient insight's 2014-2019 China mobile learning market. Retrieved from http://www.ambientinsight.com/Reports/ MobileLearning.aspx\#section1

Alia.S.S., \& Ngazis, A., N. (2014). Ada 11,5\% Pengguna Smartphone Mahal di Indonesia.Retrieved, November 26, 2014 from http://teknologi.news.viva.co.id/news/read/562546-riset--ada-11-5-pengguna- smartphone-mahal-di-indonesia

Baggaley, J. (2007). The Pandora model of collaborative distance education research: Collated interviews and responses. Distance Education, 28 (2), 245-252.

Baran, E. (2014). A review of research on mobile learning in teacher education. Educational Technology \& Society, $17(4) .17-32$.

Bidin, S., \& Ziden, A. A. (2013). Adoption and application of mobile learning in the education instrusry. Procedia-Sosialand BehaviouralSciences, 90 (InCULT 2012). 720-729.

Doi:10.1016/j.sbspro.2013.07.145

Burton, L. J., Summers, J., Lawrence, J., Noble, K., \& Gibbings, P. (2015). Digital literacy in higher education: The rhetoric and the reality. In Myths in education, learning and teaching (151-172). Basingstoke: Palgrave MacMillan.

Gusti (2014) Menkominfo: 270 Juta Pengguna Ponsel di Indonesia. Retrieved March 10, 2014 from http://ugm.ac.id/id/berita/8776- menkominfo\%3A.270.juta. pengguna.ponsel.di.indonesia

Imtinan, U. (2017). Mobile learning implementation in university environments: Implications on practice for university leadership stakeholders. In A. Murphy, H. Farley, L. E. Dyson, H. Jones (Eds). Mobile learning in highereducation in the Asia- Pacific Region (pp.379-400). Singapore: Springer.

Keegan, D. (Ed.) (2005). Theoretical Principles of DistanceEducation. London: Routledge Laurillard, D. (2007). Pedagogical forms of mobile learning: framing research questions. In N. Pachler (Ed.), Mobile learning - towards a research agenda (pp. 153-175). London: WLE Centre, Institute of Education, University of London.

Miftah, M (2012). Implementasi Teori Belajar dalam Sistem Pembelajaran Mobile Learning. Retrieved November 26, 2014 from http://www.mediapendidikan.net/index.php?option=com_content\&view=article \&id=6:teoribelajar\&catid=29:teori-belajar\&Itemid $=22$

Mobile phone internet user penetration in Indonesia from 2015 to 2022. The Statistics Portal. Retrieved February 21, 2018 from https:/www.statista.com/statistics/309017/indonesia-mobile-phoneinternet- user-penetration

Murphy, A., Farley, H.(2017). Introduction: supporting the sustainable implementation of mobile learning for higher education in the Asia-Pacific region. In A. Murphy, H. Farley, L.E. Dyson, H. Jones (Eds) Mobile Learning in HigherEducation in the Asia- Pasific Region (pp. 3-23). Singapore:Springer.

Naismith, L., Lonsdale, P., Vavoula, G., \& Sharples, M. (2004). Literature review in mobile technologies and learning. University of Birmingham:Futurelab.

O'Malley, C., Vavoula, G., Glew, J.P., Taylor, J., Sharples, M., \& Lefrere, P. (2004). WP4 - Guidelines for learning/teaching/tutoring in a mobile environment. MOBIlearn deliverable. Retrieved February 21, 2018 from http://www.mobilearn.org/download/results/guidelines.pdf

Padmo, D., Huda, N., Idrus, O., \& Ardiasih, L. (2013). Pemanfaatan pembelajaran mobile di Indonesia dan arah perkembangannya di masa mendatang, tahap I (The use of mobilelearninginIndonesiaand thedirectionof developmentinthefuture, Partl). Unpublished Research Report. Jakarta: Universitas Terbuka. 
Panjaitan, Y. (2012). Pembelajaran berbasis mobile online. Retrieved November 20, 2014 from http://edukasi.kompasiana.com/2012/05/28/pembelajaran-berbasis- mobile-online-465791.html

Schroeder, B. (2013). In A. Tsinakos \& M. Ally (Eds). Global mobile learning implementations and trends ( $\mathrm{pp}$. 105-118). China Central Radio \& TV University Press.

Sharples, M., Taylor, J., \& Vavoula, G. (2007). A theory of learning for the mobile age. In R. Andrews \& C. Haythornthwaite (Eds.), The Sage Handbook of Elearning Research (pp. 221-47). London: Sage.

Shiliang, L., \& Hongtao, S. (2013) Changing the Way of Learning: Mobile Learning in China. In A. Tsinakos \& M. Ally (Eds). Globalmobile learningimplementations and trends ( pp. 143-156). China Central Radio \& TV UniversityPress.

Shon, J.G. (2008, March). Mobile learning trends in Korea. Paper presented at the ISO/IEC JTC1/SC36 Open Forum, Seoul, Korea.

Strong, R., Ho, S. P., Odom, S. F., \& Irby, T. L. (2013). A Course focused on the critical issues in agriculture: Students' acceptance and use of mobile learning. North American Colleges and Teacher of Agriculture (NACTA) Journal, (57-64).

Susanto, D. A. (2013). Jumlah perangkat mobile di Indonesia ungguli jumlah penggunanya. Retrieved November 25, 2014 from https://www.merdeka.com/teknologi/jumlah-perangkat-mobile-diindonesia- ungguli-jumlah-penggunanya.html

Uzunboylu, H., \& Ozdamli, F. (2011). Teacher Perception for M-Learning: Scale development and deacher's Perceptions. Retrieved January 12, 2018 from https://doi.org/10.1111/j.1365-2729.2011.00415.x

World Stat (2017). Retrieved August 23, 2017 from http://www.internetworldstats.com/stats.htm 